\title{
Factors of achieving and ensuring energy security in the context of national and Euro- Atlantic security
}

\author{
Nicolae Daniel Fîţă ${ }^{1 *}$, and Emilia Grigorie ${ }^{1}$ \\ ${ }^{1}$ University of Petrosani, Universitatii Street, No.20, Petrosani, Romania
}

\begin{abstract}
Energy security, alongside with industrial, food, societal, environmental and sustainable development, information, cyber, economic, defense and national order security, etc., is part of the concept of national security of a state. The level of security of a state is the ability of that state to aggregate resources internally and gain or maintain access to external economic resources. Energy security means being ensured in terms of raw material sources, control of transportation and distribution routes and alternatives. Sufficient and available raw material resources are an urgent prerequisite for achieving energy security. Any longer interruption of energy supply has a negative effect on the economic growth, the political stability and the welfare of the citizens of a state. The following elements of energy security instability can endanger a state's energy security: risks (physical, economic, geopolitical, geostrategic, social, environmental protection, etc.); threats (terrorist action, political, industrial, economic and national instability, armed conflicts, piracy, etc.); dangers (lack of energy supply and/or raw materials, the finite nature of energy resources, use of energy as a pressure instrument or energy weapon, use of energy revenues to support undemocratic regimes, high energy costs for developing countries and global climate change) and vulnerabilities (natural and/or anthropogenic hazards). For the purpose to ensure the stability of national and EuroAtlantic security, the following factors are proposed by authors to achieve and ensure energy security: 25 proposed way to achieving energy security; 8 proposed way to ensuring energy security, and 9 proposed scenarios to quantification energy security almost complete. The final conclusion is: the energy security of a state is in fact the national security of that state.
\end{abstract}

\section{The concept of energy security}

\subsection{Definition}

The energy security of a state represents: the existence, accessibility and provision of (re) finished sources of raw materials (oil, natural gas, coal, hydrocarbons, uranium, etc.) and renewable, sufficient and available; clear and stable international / European trade

\footnotetext{
*Corresponding author: daniel.fita@yahoo.com
} 
agreements on access to these (re) finite sources of imported raw materials; price stability of these (re) finite sources of raw materials; control of transport and distribution routes and alternatives of finite (re) sources of raw materials; the safety and security of the transformation of these finite (re) sources of raw materials into electricity; clear and stable trade agreements on trade in electricity with neighboring countries or those of the European Union; electricity price stability; control of electricity transmission and distribution routes; accessibility of each consumer (domestic / industrial) to electricity.

The security level of a state is given by the ability of that state to aggregate resources domestically, to gain and maintain access to external economic resources and any longer interruption of energy supply has a negative effect on economic growth, stability political and welfare of the citizens of a state. Energy security plays a very important role in the economic security of a state, which is why it must be taken in the most serious way, and not giving importance to energy security can cause catastrophic damage with insecurity and instability, endangering the welfare of the people. [5] [6]

\subsection{Dimensions}

Energy security is perceived as an umbrella covering energy concerns:

- economical growth;

- political power.

As distinct and overlapping dimensions of energy security, experts from the German Center for Applied Political Research identify:

- the dimension of domestic policy (state of political stability);

- $\quad$ economic dimension (resources and energy markets);

- the geopolitical dimension (international energy trade);

- $\quad$ the size of the security policy (securing energy infrastructures);

- military dimension (national security and safety).

Table 1. Particularities of energy security dimensions

\begin{tabular}{|c|c|}
\hline DIMENSIONS & PARTICULARITIES OF ENERGY SECURITY \\
\hline $\begin{array}{l}\text { Internal Policy } \\
\text { Dimension }\end{array}$ & $\begin{array}{l}\text { - investments in the maintenance and development of the energy } \\
\text { infrastructure (new constructions of energy objectives or refurbishments of } \\
\text { the existing ones; } \\
\text { - intervention in case of energy emergency (breakdowns, incidents and / or } \\
\text { accidents); } \\
\text { - increasing energy efficiency; } \\
\text { - orientation of the energy mix towards alternative energies; } \\
\text { - securing jobs and workers. }\end{array}$ \\
\hline $\begin{array}{l}\text { Economical } \\
\text { Dimension }\end{array}$ & $\begin{array}{l}\text { - clear rules for the functioning of the oil, natural gas and electricity markets; } \\
\text { - plans for the development of energy transmission networks; } \\
\text { - long-term contracts; } \\
\text { - diversification of energy sources and highways; } \\
\text { - technological innovation in the energy field; } \\
\text { - increasing the reliability of the national energy and power system. }\end{array}$ \\
\hline $\begin{array}{l}\text { Geopolitical } \\
\text { Dimension }\end{array}$ & $\begin{array}{l}\text { - concerted action to secure international trade in oil, natural gas and } \\
\text { electricity; } \\
\text { - adoption of a global legal framework in the field of transnational energy } \\
\text { services; } \\
\text { - the trend of renationalization of infrastructure and energy companies; } \\
\text { - the need for strategic concepts and overall approaches, especially in } \\
\text { relation to fragile states. }\end{array}$ \\
\hline
\end{tabular}




\begin{tabular}{|c|l|}
\hline $\begin{array}{c}\text { Security Policies } \\
\text { Dimension }\end{array}$ & $\begin{array}{l}\text { - close cooperation with states vulnerable to terrorist attacks on energy } \\
\text { infrastructure or piracy, including through the exchange of information, } \\
\text { training and good practice debates; } \\
\text { - Highly industrialized states consuming oil, gas and electricity, directly or } \\
\text { through the EU or NATO, should expand their commitment to risk } \\
\text { management capabilities, crisis response and military and police training. }\end{array}$ \\
\hline $\begin{array}{c}\text { Military } \\
\text { Dimension }\end{array}$ & $\begin{array}{l}\text { - it manifests itself internally in the defense policies of the most important } \\
\text { actors of the energy market, which ultimately seek the use of military means } \\
\text { to maintain advantageous positions. }\end{array}$ \\
\hline
\end{tabular}

\subsection{Components}

\section{a) Energy primary sources}

The development of a strong energy industry of a state is conditioned by the existences of primary energy sources that are characterized by: diversity, accessibility, safety, stable prices, ensuring the desired quantities for as long as possible. [5] [6]

In relation to these conditions, the attention of the energy industry is directed towards an increasingly diverse range of primary energy sources, with increasingly different particularities. Through the conversion carried out in specialized installations, these sources cover the demand for electricity and heat of the company.

Conventionally, primary energy sources are divided into two broad categories:

- finite sources (oil, natural gas, coal, hydrocarbons, uranium, etc.) - finite sources of primary energy are considered to be limited both in time and space. They are able to cover the needs of human society only for a limited period of time. The size of this time period depends on the volume of primary energy reserves to which human society has access;

- renewable sources - renewable sources are not limited in time, but they are not able to cover the needs of human society that are increasingly high from one year to another.

\section{b) Electricity}

Electricity production is the process of transforming various forms of primary energy into electricity, in specialized installations of high complexity, called power plants. The evolution of electricity consumption has made the power plants bigger and bigger, their installed powers being limited by technological, economic, environmental or security restrictions. The power plant is a set of complex installations, which ensure the conditions for the conversion of primary energy into electricity. Two opposing conceptions of energy production can be highlighted:

- centralized design, based on high power power plants, which use primary sources with high energy concentration (fossil or nuclear fuels). The power of these plants is usually superior to local consumption, implying the existence of a system of transmission and distribution of electricity. The ensemble of power plants and electric transmission networks, operated and managed in a unitary conception constitutes a National Energy System. In Romania, the activity of electricity transmission, management and dispatching of the National Energy System - SEN, is carried out through the National Electricity Transmission Company Transelectrica SA, which is also the system operator. The electricity transmission activity is carried out through the National Electricity Transmission Network RNTEE (electricity network of national and strategic interest with nominal line voltage higher than $110 \mathrm{kV}$, ie $220 \mathrm{kV}, 400 \mathrm{kV}$ and $750 \mathrm{kV}$ ), formed from: 81 power substations (1 - 750 kV, $38-400 \mathrm{kV}$, and $42-220 \mathrm{kV}), 8931,6 \mathrm{~km}$. overhead 
power lines - OHL $(154,6 \mathrm{~km}$ - - 750 kV, 4703,7 km. - $400 \mathrm{kV}$ and 4035,2 km. - 220

$\mathrm{kV}$ ) and 218 transformation units totaling $37794 \mathrm{MVA}$; [7]

- the concept distributed, with small sources, located next to consumers. It is generally based on the use of light, low-energy primary sources (solar, wind, etc.). The plant is designed strictly to cover local consumption, eliminating the need to transport electricity remotely.

\section{Elements of energy security instability}

The following elements are generating energy security instability: risks; threats; dangers and vulnerabilities. [9]

\subsection{Risks}

The main risks to energy security instability are:

- physical risks - refers to the possibility of a physical interruption of the supply and / or supply of energy resources (oil, natural gas, coal, uranium, electricity, etc.), generated by the depletion and / or abandonment of that energy source, or temporary interruptions caused by force majeure (natural disasters);

- economic risks - refers to the vulnerability of the economic environment under the pressure exerted by energy price fluctuations, which is the guiding price of energy. Economic risk derives from the volatility of markets and oil prices;

- geopolitical and geostrategic risks - energy is a vital source of interest for both producing and consuming countries. Inequitable access to resources, the special geopolitical interests of the great powers, are potential sources of conflict both between consuming countries and between them and producing countries. Political conflicts in energy-producing regions, including terrorist manifestations, pose a severe threat to both current energy supplies and the prospects of the large investments needed to develop resources to their full potential;

- social risks - the instability of the energy supply, whether it is associated with disorderly price fluctuations, or relations with producing countries, or geopolitical crises, can cause serious social disruptions but also changes in corporate behavior;

- risks associated with environmental protection - the risks of environmental disturbances come from sources such as: accidents caused by the chain of energy operations, technical accidents, but especially due to pollutant emissions generated by the consumption of energy systems. Increasing energy security and tackling climate change are two of the major concerns and challenges of today's society. Both are intrinsically linked to how we produce and consume energy. Both energy security and climate change have implications for foreign and security policies.

\subsection{Threats}

The main threats to energy security instability are:

- terrorism (terrorist attack / cyber attack);

- $\quad$ political instability (political unpredictability);

- $\quad$ armed conflicts (national instability);

- piracy (commercial / industrial / economic instability). 


\subsection{Dangers}

The main dangers to energy security instability are:

- lack of supply of oil, natural gas, coal, uranium and electricity for technical or other reasons;

- the finite nature of energy resources;

- the use of energy as a pressure instrument or energy weapon;

- the use of energy revenues to support undemocratic regimes;

- global climate change;

- high energy costs for developing countries.

\subsection{Vulnerabilities}

The main vulnerabilities to energy security are:

- natural hazards (hurricanes, floods, earthquakes, fires, tsunamis, etc.);

- anthropogenic hazards (accidents, incidents, damages, corruption, incompetence, sabotage, theft).

\section{Factors of achieving and ensuring energy security}

\subsection{Ways to achieving energy security}

The main proposed ways to achieving energy security are:

Critical factors:

A. Possession of energy resources (strong points):

1) possesion of national energy resources: oil, natural gas, coal, uranium, etc.;

2) possesion of national renewable energy sources (alternative energy): hydraulic, wind, photovoltaic, etc.

B. Possession of energy critical infrastructure (strong points):

1) possession of national critical infrastructures for oil extraction: maritime and underground probes;

2) possession of national critical infrastructures for oil transport from offshore platforms to continental points: sea vessels;

3) possession of national critical infrastructure for electricity generation: power plant: thermal, hidroelectric, nuclear, wind, photovoltaic, etc.;

4) possession of cross-border critical infrastructure (euro-atlantic) for supply with energy resources: oil pipelines, gas pipelines, oil station, gas stations, railways, sea ports, sea and river vessels, etc.;

5) possession of cross-border critical infrastructures (euro-atlantic) for supply with electricity: power substations and overheadlines $400 \mathrm{kV}$;

6) possession of national critical infrastructures for energy transport: oil and gas pipelines, oil and gas stations, railways, sea ports, sea and river vessels, etc.;

7) possession of critical infrastructures for refining of petroleum products: refineries;

8) possession of national critical infrastructure for electricity transmission: national power grid (power substation and overheadlines $400 \mathrm{kV}$ );

9) possession of critical infrastructures for excess capacity and/or emergency stocks of energy resources: marine, underground, earth or overland storage tanks for oil, fuel, natural gas, coal, uranium, etc;

10) possession of surplus (extra) critical infrastructures for transporting oil and natural gas: oil and gas stations, oil and gas pipelines, railway wagons, etc.; 
11) possession of surplus (extra) critical infrastructures for transporting coal and uranium: railway wagons;

12) possession of surplus (extra) critical infrastructures for electricity transmission: power plants, power substation and overheadlines $400 \mathrm{kV}$.

C. Possession of national and international agreement (strong points):

1) diversification of energy supply sources;

2) acces to imported energy resources;

3) the existence of a single oil market;

4) the existence of a single natural gas market;

5) the existence of a single electricity market.

Important factors:

1) mutual interdependence between government and energy companies: sector of activity: oil, natural gas, coal, uranium and electricity;

2) development and stability of relations between producers, distributors, suppliers and consumers: reciprocity of interdependence;

3) promoting and creating a proactive physical security framework involving producers, distributors, suppliers and consumers: sector of actvity: energy resources and critical energy infrastructure;

4) transparency and fairness of information provided to the public: during and after an energy crisis;

5) investment in modern energy technology: sector of activity: oil, natural gas, coal, uranium and electricity;

6) mandatory research, development and innovation on energy stability in the very long term and/or during energy transition periods.

\subsection{Ways to ensuring energy security}

The main proposed ways to ensuring energy security are:

Critical factors:

1) diversification of sources of supply with the following energy resources: oil, natural gas, coal, uranium, etc.;

2) diversification of sources of supply with electricity;

3) diversification of energy transport routes: oil, natural gas, coal, uranium, electricity;

4) promotion of cross-border interconnection projects in following sector: oil, naturale gas, coal, uranium and electricity;

5) control of the main transmission and distribution lines for: oil, natural gas, coal, uranium and electricity;

6) control of alternative energy sources;

Important factors:

1) reforming and/or stability the energy policy of the European Union or the world;

2) the formation of an Integrated Security Management for each economic entity involved in the energy security chain, with the active and pragmatic involvement of the State on: secure of installations - Management of Critical Infrastructure Protection and security of workplaces and personnel - Occupational Health and Safety.

\subsection{Energy security quantification scenarios}

The main proposed scenarios to quantification energy security almost complete are: 
1) the establishment of a national entity regarding: ensuring, controlling, stability and increasing national energy security;

2) the establishment of a european entity regarding: ensuring, controlling, stability and increasing european energy security;

3) the establishment of a global entity regarding: ensuring, controlling, stability and increasing global energy security;

4) establishment of a Global Energy Dispatch regarding: ensuring, controlling, stability and increasing global energy security;

5) establishment of a Global Directorate regarding: ensuring, controlling, stability and increasing global energy security;

6) ensuring, controlling, stability and increasing global energy security by ONU means or any other transparent means;

7) ensuring, controling, stability and increasing of national, european or global energy security within regional economic, political and military bodies with the aim of balancing the dynamics of international energy exchanges;

8) the exploration of new energy sources;

9) reducing dependence on hydrocarbon energy resources: oil and natural gas.

\section{Conclusions}

The increasing occurrence of cases of energy collapse worldwide manifested by lack of energy (primary energy resources or electricity) in final consumers and the desire of the world's major energy powers to own and control the entire global energy chain for the use of electricity or resources primary energy as a tool of pressure or energy weapon in the context of profitability, makes this paper of great importance and relevance. The lack of energy supply (primary energy resources or electricity) of final consumers leads to the onset of crises that cause societal imbalance causing extreme damage to the safety of citizens, industry, the national economy and thus national security, because all sectors of a state economy depend on primary energy resources or electricity.

For the purpose to ensure the stability of national and Euro-Atlantic security, the following factors are proposed by authors to achieve and ensure energy security:

- 25 proposed way to achieving energy security:

- 19 critical factors (strong points);

- 6 important factors.

- 8 proposed way to ensuring energy security:

- 6 critical factors (strong points);

- 2 important factors.

- 9 proposed scenarios to quantification energy security almost complete.

In this context, the energy security of a state is in fact the national security of that state.

\section{References}

1. Parliament of Romania Law 51/1991 on the National Security of Romania, Bucharest, (1991)

2. Presidential Administration National Defense Strategy for the period 2015 - 2019, Bucharest, (2015)

3. P. Duțu, Asymmetric threats or hybrid threats: conceptual delimitations for the substantiation of national security and defense, Center for Strategic Defense and Security Studies, "Carol I" National Defense University Publishing House, (2013)

4. C. Ana, C. Moarcăș, Social security law, C.H. Beck, Bucharest, (2013) 
5. Ministry of Energy Romania's Energy Strategy 2016-2030, with the perspective of 2050

6. C. Băhnăreanu, Energy security, Center for Strategic Defense and Security Studies, "Carol I" National Defense University Publishing House, (2008)

7. CNTEE Transelectrica SA www.transelectrica.ro

8. Dick, Lugar Energy Security is National Security http://lugarsenate.gov/energy/security/index.html.

9. N. Dolghin, Al. Sarcinschi, M.S. Dinu, Risks and threats to Romania's security. News and Perspective, Center for Strategic Defense and Security Studies, "Carol I" National Defense University Publishing House, (2004) 